\title{
Evaluation of Certain Physico-chemical and Sensory Qualities of Chicken Nuggets Incorporated with Black Rice (Oryza sativa L.) Flour
}

K. Richa, S.K. Laskar, A. Das, M. Hazarika, S. Choudhury, S. Sonowal'1 , S. Upadhyay²

10.18805/ajdfr.DR-1777

\begin{abstract}
Background: The present work was conducted to study the effect of incorporation of three different levels of black rice flour along with other non- meat ingredients on certain physico-chemical and sensory qualities of chicken nuggets.

Methods: The chicken nuggets were prepared with the formulations i.e. control ( $0 \%$ black rice flour), $T_{1}$ ( $1 \%$ black rice flour), $T_{2}$ ( $3 \%$ black rice flour) and $\mathrm{T}_{3}(5 \%$ black rice flour). Emulsion stability (ES) and cooking yield were recorded for treated and control formulations on the day of preparation. The $\mathrm{pH}$, water activity, TBARS value and sensory qualities were evaluated on day $1,5,10$ and 15 .

Result: Addition of black rice flour at 1,3 and 5 per cent level resulted no adverse effect on physicochemical qualities of chicken nuggets. Sensory evaluation revealed that chicken nuggets could be prepared satisfactorily with addition of up to 5 per cent black rice flour without adversely affecting the organoleptic qualities of the products.
\end{abstract}

Key words: Black rice, Chicken nuggets, Physicochemical study, Sensory qualities.

\section{INTRODUCTION}

Poultry meat is the fastest growing component to cater the need for global demand of meat. In India, the total poultry population is 851.81 million (20 th Livestock Census). Chicken shares the largest portion of poultry meat produced in India. The culture, traditions, customs and taboos influence meat consumption largely especially in the rural societies. Preference for poultry meat over other meat is due to its relatively lower price; moreover, there is no religious taboo regarding consumption of poultry meat. As per USDA in 2016, India's per capita consumption of poultry meat was estimated at around $3.1 \mathrm{~kg}$ per year, which is much lower compared to the world average of around $17 \mathrm{~kg}$ per year. Meat consumption pattern in terms of quality and quantity has found to be strongly related to the socio economic status of the consumer throughout the world. Increasing income among middle class and increasing urbanization has increased preference for packaged and ready to eat poultry products in India. Large numbers of national and multinational companies have entered the domestic processed meat market in urban areas. However, along with the increasing demand for processed meat products there is also increase in health consciousness among the consumers. Non-meat ingredients derived from a variety of plant and animal sources are used extensively as fillers, binders and extenders in comminuted meat systems to improve the quality and to reduce the production cost. Their prudent incorporation results in improvement of the quality of meat products. (Reddy et al, 2015). Cereal flours such as wheat, corn and rice are used as main group of fillers for preparation of processed products. $\overline{\text { Department of Livestock Products Technology, College of Veterinary }}$ Science, Assam Agricultural University, Khanapara, Guwahati-781 022, Assam, India.

${ }^{1}$ Department of Veterinary Public Health, College of Veterinary Science, Assam Agricultural University, Khanapara, Guwahati-781 022, Assam, India.

${ }^{2}$ AICRP on PHET, Department of Livestock Products Technology, College of Veterinary Science, Assam Agricultural University, Khanapara, Guwahati-781 022, Assam, India.

Corresponding Author: S.K. Laskar, Department of Livestock Products Technology, College of Veterinary Science, Assam Agricultural University, Khanapara, Guwahati-781 022, Assam, India. Email: saurabhlaskar@gmail.com

How to cite this article: Richa, K., Laskar, S.K., Das, A., Hazarika, M., Choudhury, S., Sonowal, S., Upadhyay, S. (2021). Evaluation of Certain Physico-chemical and Sensory Qualities of Chicken Nuggets Incorporated with Black Rice (Oryza sativa L.) Flour. Asian Journal of Dairy and Food Research. DOI: 10.18805/ajdfr.DR-1777.

Submitted: 30-06-2021 Accepted: 11-10-2021 Online: 16-11-2021

Black rice is a type of the rice species Oryza sativa L. mainly cultivated in Asia. This rice is getting much attention among the food scientists in recent years because of its high nutritive value and antioxidative properties. Demand for this rice is growing fast in the USA and European countries due to its value as a healthy food and its attractive organic food color. Ichikawa et al., (2001) reported that black rice is efficient and two fold stronger with respect to antioxidant activities of blueberries.

In this context, the proposed research programme was envisaged to study the certain physicochemical and sensory qualities of chicken nuggets incorporated with black rice flour. 


\section{MATERIALS AND METHODS}

Chickens were purchased from nearby market and were slaughtered in the semi-mechanized poultry-dressing unit of the LPT Department, College of Veterinary Science, Khanapara, Guwahati. Deboned meat along with heart, liver, gizzard, skin, fat harvested was packed separately in food grade polyethylene bags and then stored at $4 \pm 1^{\circ} \mathrm{C}$ temperature for 24 hours. After that, they were cut into small cubes of $3 \mathrm{~cm}$ size and then minced in a mechanical mincer through $4 \mathrm{~mm}$ plate. Curing ingredients viz. salt ( $2 \%)$, sodium tripolyphosphate $(0.3 \%)$ and sodium nitrite $(150 \mathrm{ppm})$ were added to the minced meat and thoroughly mixed and then stored at $4 \pm 1^{\circ} \mathrm{C}$ for next 24 hours to facilitate proper curing. After that different levels of black rice flour i.e. 1, 3, 5\% along with other spices and condiments, soya bean flour, egg white, ice flakes were added to the minced meat and mixed thoroughly to prepare the meat emulsion and in the control sample black rice flour was absent.

Chicken nuggets were prepared by filling the emulsions of different formulations in separate stainless steel moulds and cooked in hot water maintained at $80^{\circ} \mathrm{C}$ for 45 minutes. The cooked meat blocks were given a cold shower and chilled in refrigerator for 6hours. The chilled blocks were then cut into shape $(1.5 \times 0$. nuggets of rectangular 75 inch) and vacuum packed in HDPE pouches and stored under refrigeration.

The emulsion stability of the samples was detected by the method described by Mongale et al., (1985). The water holding capacity (WHC) was measured by the technique described by Wardlaw et al. (1973) while the $\mathrm{pH}$ of the chicken nuggets were determined by the method of Pippen et al., (1965). The water activity of the nuggets was determined with the help of a water activity meter (Make: AQUA LAB, Model: 4TE) and the TBARS value of chicken nuggets was determined by the method described by Witte et al., (1970).

Total calories in the cooked chicken nuggets were calculated on the basis of 100 portions using the Atwater value for fat $(9.00 \mathrm{Kcal} / \mathrm{g})$, protein $(4.02 \mathrm{Kcal} / \mathrm{g})$ and carbohydrate $(4.00 \mathrm{Kcal} / \mathrm{g})$. The samples were evaluated for colour, flavour, juiciness, tenderness and overall acceptability by using a 9-point hedonic scale as described by Bratzler, (1971) .

Total five batches of the products were prepared with each formulation for the proposed study. The data obtained from the above study were analysed statistically by a software SAS (SAS 9.3 software).

\section{RESULTS AND DISCUSSION Physico-chemical qualities}

The black rice treated products had significantly $(P<0.01)$ higher emulsion stability than the control product (Table 1). The higher emulsion stability in the treated products could be due to the addition of black rice flour, which had starch as a main component, which possesses unique gelatinization properties and binding capacity (Barbosa et al., 2006). Park and Kim (2016), also observed that pork sausage extended with different levels of black rice flour had revealed significant $(P<0.05)$ increase in the emulsion stability with increase in the level of black rice powder.

The chicken nuggets treated with different levels of black rice flour recorded significantly $(P<0.01)$ higher cooking yield values in comparison to the control product (Table 1). This might be due to the fact, that yield of the meat products mainly depends upon batter stability and since treated products had comparatively higher emulsion stability, there was minimum water loss while cooking and achieved high product yield (Verma and Banerjee, 2012). Jebin et al. (2012) also reported an increasing trend in the cooking yield from control to the treated duck salamis incorporated with rice flour. Similar significant $(<0.05)$ increase in the cooking yield with increase in black rice powder content in pork patties was reported by Park et al. (2017).

The black rice treated products had showed a higher trend in water holding capacity values compared to the control product (Table 1). However, the difference was nonsignificant. The slight increase in the water holding capacity might be due to the high retention of water by increased levels of rice flour incorporation in the products (Reddy et al., 1999). Lee et al. (2003) also reported that the addition of grain powder prevents a certain degree of water loss and grain powder particularly improves the water holding capacity.

The $\mathrm{pH}$ values of chicken nuggets showed a significantly $(P<0.01)$ increasing trend in the treated formulations as compared to control (Table 2). The increase in $\mathrm{pH}$ with increasing levels of black rice flour might be the due to the high $\mathrm{pH}$ (6.68) of the black rice flour (Park et al., 2017). Storage studies revealed that the mean $\mathrm{pH}$ value of chicken nuggets both for control and treated products increased significantly $(P<0.01)$ from $5^{\text {th }}$ day along with the increase in storage period at refrigeration temperature. The increase in $\mathrm{pH}$ might be due to the accumulation of metabolites of bacterial action on meat and meat products and deamination

Table 1: Effect of incorporation of Black Rice Flour on Emulsion Stability ( $\mathrm{ml}$ of oil per $100 \mathrm{~g}$ of emulsion), Cooking yield and WHC and calorie value $(\mathrm{Kcal} / 100 \mathrm{~g})$ of chicken nuggets (Mean $\pm \mathrm{SE})$.

\begin{tabular}{|c|c|c|c|c|}
\hline Parameters & $\begin{array}{l}\text { Control } \\
(0 \%)\end{array}$ & $\begin{array}{c}\mathrm{T}_{1} \\
(1 \%)\end{array}$ & $\begin{array}{c}\mathrm{T}_{2} \\
(3 \%)\end{array}$ & $\begin{array}{c}\mathrm{T}_{3} \\
(5 \%)\end{array}$ \\
\hline Emulsion stability (ES) & $0.76^{a} \pm 0.11$ & $0.48^{b} \pm 0.07$ & $0.44^{b} \pm 0.04$ & $0.38^{b} \pm 0.04$ \\
\hline Cooking yield & $93.38^{a} \pm 0.20$ & $93.98^{\mathrm{a}} \pm 0.24$ & $94.88^{\mathrm{b}} \pm 0.40$ & $95.93^{\mathrm{c}} \pm 0.14$ \\
\hline Water holding capacity (WHC) & $46.00^{\mathrm{a}} \pm 1.25$ & $46.67^{a} \pm 1.05$ & $48.67^{a} \pm 1.33$ & $50.00^{\mathrm{a}} \pm 1.49$ \\
\hline Calorie value & $217.27^{\mathrm{a}} \pm 0.60$ & $211.70^{\mathrm{b}} \pm 1.19$ & $206.95^{\circ} \pm 1.51$ & $203.01^{\mathrm{c}} \pm 1.91$ \\
\hline
\end{tabular}

$\mathrm{N}=5$; Mean with superscript bearing different alphabet (small) row wise differ significantly. 
of meat proteins (Bhat et al., 2013). Reddy et al. (2015) reported an increase in the values of $\mathrm{pH}$ with increase in the storage period in chicken meat patties, which was related with the increase in microbial load.

The water activity value revealed a significantly $(P<0.05)$ decreasing trend from day 1 to 15 days of storage period and also a significant $(P<0.05)$ difference was observed in the mean values of water activity among control and treated formulations. The decrease in the water activity during the progressive storage period might be due to the growth of microorganisms, which utilized water for their growth and multiplication (Dharmaveer et al., 2007).

Thiobarbituric acid reactive substances (TBARS) value revealed a significantly $(P<0.01)$ increasing trend from day 1 to $15^{\text {th }}$ day of storage period and also a significant difference $(P<0.01)$ was observed in the mean values of TBARS of control and treated formulations (Table 2). The increase in TBARS values on storage might be attributed to oxygen permeability of packaging material that led to lipid oxidation and production of volatile metabolites during storage (Kumar et al., 2013).

The lower TBARS value recorded in the chicken nuggets incorporated with the black rice flour might be due to the antioxidant property of black rice. Hu et al. (2003) and Philpott et al. (2006) reported that the anthocyanins present in the black rice possess remarkable antioxidant activities and is 10 times higher than in brown rice bran (Goffman and Bergman, 2004). In the present study, the significantly $(\mathrm{P}<0.01)$ lower calorie value from the control to the treated formulations (Table 1) might be due to the lower fat content in the treated formulations as compared to the control.

\section{Sensory qualities}

In the present study, chicken nuggets treated with different levels of black rice flour had significantly $(<0.01)$ higher colour scores values in comparison to the control product (Table 3). These findings are in agreement with the findings of Pereira et al. (2016) who reported an increase in colour scores with the addition of rice flours in pork sausage. The chicken nuggets treated with different levels of black rice flour had significantly $(<0.01)$ higher flavour values in comparison to the control product. This might be due to increased levels of black rice flour in the treated products. Laskar et al. (2013) also recorded increase in flavour scores in chevon salamis with the gradual increase in the level of

Table 2: Effect of incorporation of black rice flour on $\mathrm{pH}$, water activity $\left(\mathrm{a}_{\mathrm{w}}\right)$ and TBARS value (mg malonaldehyde/ $\mathrm{kg}$ ) of chicken nuggets (Mean \pm Se).

\begin{tabular}{|c|c|c|c|c|}
\hline Treatment & Days & $\mathrm{pH}$ & $a_{w}$ & TBA (mg malonaldehyde/kg) \\
\hline \multirow[t]{4}{*}{ Control } & 1 & ${ }^{A} 6.40 \pm 0.02$ & ${ }^{A} 0.9483^{a} \pm 0.001$ & ${ }^{A} 0.30^{a} \pm 0.02$ \\
\hline & 5 & ${ }^{8} 6.50 \pm 0.01$ & ${ }^{A B} 0.9389^{a} \pm .002$ & ${ }^{\mathrm{B}} 0.50^{\mathrm{a}} \pm 0.02$ \\
\hline & 10 & ${ }^{8} 6.56_{a} \pm 0.02$ & ${ }^{\mathrm{B}} 0.9365^{\mathrm{a}} \pm .0001$ & ${ }^{c} 0.66^{a} \pm 0.02$ \\
\hline & 15 & ${ }^{c} 6.65_{a} \pm 0.02$ & ${ }^{\mathrm{c}} 0.9311^{\mathrm{a}} \pm .0001$ & ${ }^{\mathrm{D}} 0.90^{\mathrm{a}} \pm 0.02$ \\
\hline \multirow[t]{4}{*}{$\mathrm{T}_{1}$} & 1 & ${ }^{\mathrm{A}} 6.41_{\mathrm{ab}} \pm 0.01$ & ${ }^{A} 0.9487^{\mathrm{a}} \pm 0.01$ & ${ }^{A} 0.29^{a} \pm 0.02$ \\
\hline & 5 & ${ }^{\mathrm{B}} 6.51_{\mathrm{a}} \pm 0.02$ & ${ }^{A B} 0.9393^{\mathrm{a}} \pm 0.01$ & ${ }^{\mathrm{B}} 0.47^{\mathrm{a}} \pm 0.01$ \\
\hline & 10 & ${ }^{\mathrm{c}} 6.59_{\mathrm{ab}} \pm 0.03$ & ${ }^{\mathrm{B}} 0.9363^{\mathrm{a}} \pm 0.002$ & ${ }^{\mathrm{c}} 0.62^{\mathrm{ab}} \pm 0.02$ \\
\hline & 15 & ${ }^{\mathrm{D}} 6.67_{\mathrm{ab}} \pm 0.02$ & ${ }^{c} 0.9321^{a} \pm 0.002$ & ${ }^{\mathrm{D}} 0.87^{\mathrm{a}} \pm 0.06$ \\
\hline \multirow[t]{4}{*}{$\mathrm{T}_{2}$} & 1 & ${ }^{A} 6.41 \mathrm{ab} \pm 0.01$ & ${ }^{\mathrm{A}} 0.9492^{\mathrm{a}} \pm 0.001$ & ${ }^{A} 0.28^{a} \pm 0.02$ \\
\hline & 5 & ${ }^{\mathrm{B}} 6.52 \mathrm{ab} \pm 0.02$ & ${ }^{A} 0.9395^{a} \pm 0.005$ & ${ }^{\mathrm{B}} 0.46^{\mathrm{ab}} \pm 0.01$ \\
\hline & 10 & ${ }^{\mathrm{c}} 6.60 \mathrm{ab} \pm 0.03$ & ${ }^{\mathrm{AB}} 0.9377^{\mathrm{a}} \pm 0.002$ & ${ }^{\mathrm{B}} 0.60^{\mathrm{ab}} \pm 0.03$ \\
\hline & 15 & ${ }^{\mathrm{D}} 6.69 \mathrm{ab} \pm 0.02$ & ${ }^{\mathrm{B}} 0.9337^{\mathrm{a}} \pm 0.002$ & ${ }^{c} 0.81^{b} \pm 0.07$ \\
\hline \multirow[t]{4}{*}{$\mathrm{T}_{3}$} & 1 & ${ }^{A} 6.42_{b} \pm 0.02$ & ${ }^{\mathrm{A}} 0.9494^{\mathrm{a}} \pm 0.001$ & ${ }^{A} 0.26^{\mathrm{b}} \pm 0.03$ \\
\hline & 5 & ${ }^{\mathrm{B}} 6.52_{\mathrm{b}} \pm 0.01$ & ${ }^{\mathrm{A}} 0.9401^{\mathrm{a}} \pm 0.001$ & ${ }^{\mathrm{B}} 0.42^{\mathrm{b}} \pm 0.02$ \\
\hline & 10 & ${ }^{c} 6.64_{b} \pm 0.02$ & ${ }^{\mathrm{A}} 0.9381^{\mathrm{a}} \pm 0.001$ & ${ }^{\mathrm{B}} 0.58^{\mathrm{b}} \pm 0.02$ \\
\hline & 15 & $\mathrm{D} 6.72_{b} \pm 0.01$ & ${ }^{\mathrm{B}} 0.9354^{\mathrm{a}} \pm 0.001$ & ${ }^{c} 0.73^{b} \pm 0.06$ \\
\hline
\end{tabular}

$\mathrm{N}=5$; Mean with subscript bearing different alphabet (small) row wise differ significantly.

Mean with superscript bearing different alphabet (capital) column wise differ significantly.

Table 3: Effect of incorporation of black rice flour on sensory qualities of chicken nuggets (Mean $\pm S E$ ).

\begin{tabular}{lccccr}
\hline \multirow{2}{*}{ Group } & \multicolumn{5}{c}{ Organoleptic qualities } \\
\cline { 2 - 6 } & Colour & Flavour & Tenderness & Juiciness & Overall acceptability \\
\hline Control & $7.51^{\mathrm{a}} \pm 0.06$ & $7.32^{\mathrm{a}} \pm 0.08$ & $7.40^{\mathrm{a}} \pm 0.08$ & $7.34^{\mathrm{a}} \pm 0.01$ & $7.41^{\mathrm{a}} \pm 0.05$ \\
$\mathrm{~T}_{1}$ & $7.71^{\mathrm{a}} \pm 0.08$ & $7.68^{\mathrm{b}} \pm 0.09$ & $7.74^{\mathrm{b}} \pm 0.07$ & $7.60^{\mathrm{a}} \pm 0.05$ & $7.68^{\mathrm{b}} \pm 0.02$ \\
$\mathrm{~T}_{2}$ & $8.06^{\mathrm{b}} \pm 0.07$ & $8.11^{\mathrm{c}} \pm 0.05$ & $7.97^{\mathrm{c}} \pm 0.05$ & $7.94^{\mathrm{b}} \pm 0.06$ & $8.03^{\mathrm{c}} \pm 0.04$ \\
$\mathrm{~T}_{3}$ & $8.17^{\mathrm{b}} \pm 0.05$ & $8.26^{\mathrm{c}} \pm 0.05$ & $8.17^{\mathrm{d}} \pm 0.03$ & $8.11^{\mathrm{b}} \pm 0.09$ & $8.18^{\mathrm{d} \pm 0.04}$ \\
\hline
\end{tabular}

$\mathrm{N}=5$; Mean with superscript bearing different alphabet (small) row wise differ significantly. 
glutenous rice flour as compared to the control group.In respect of tenderness, significantly $(<0.01)$ higher values were revealed in treatment groups compared to the control product. Similar to present study, Hwang et al. (2009) reported a significant $(P<0.05)$ increase in the tenderness scores of duck meat sausages incorporated with different cereal flours like rice, wheat etc. and he further stated that, this might be due to higher water absorption capacity of rice flour after heat treatment. In the present study, significantly $(<0.01)$ higher juiciness values were observed in treatment groups in comparison to the control product. The higher scores for juiciness might be because of increased moisture retention. Yi et al. (2012) who reported that the juiciness value of beef patties extended with the glutinous rice flour was higher compared to the control one. Gao et al. (2014) reported that the addition of glutinous rice flour in pork patties significantly $(P<0.05)$ improved the juiciness in the treated products compared to control sample. The chicken nuggets treated with different levels of black rice flour had significantly $(<0.01)$ higher overall acceptability values in comparison to the control product. The present finding was in close agreement with the findings of Hussein (2015) who reported that the overall acceptability scores recorded in the fish fingers incorporated with the black rice flour was higher than the control one.

\section{CONCLUSION}

Considering the various Physicochemical parameters and the organoleptic characteristics, the treatment $\mathrm{T}_{3}$ with $5 \%$ black rice was found to be better among the other groups. Therefore, chicken nuggets can be prepared successfully with addition of upto $5 \%$ levels of black rice flour without adversely affecting the various physicochemical parameters and are organoleptically acceptable.

\section{ACKNOWLEDGEMENT}

The authors are grateful to the Department of Livestock Products Technology and All India Co-ordinated Research Project on Post Harvest Engineering and Technology, College of Veterinary Science, AAU for providing financial support and necessary infrastructure facility to carry out the research work.

\section{REFERENCES}

Barbosa, L.N., Garcia, L.V., Tolotti, K.D., Goellner, T., Ruiz, W.A. and Santo, M.E. (2006). Elaboracao de embutido tipo mortadela com farinha de arroz. Vector, Rio Grande. 16: 11-20.

Bhat, Z.F., Pathak, V. and Fayaz, H. (2013). Effect of refrigerated storage on the quality characteristics of microwave cooked chicken seekh kababs extended with different non-meat proteins. Journal of Food Science and Technology. 50: 926-93.

Bratzler, L.J. (1971). Palatability Factors and Evaluation. Science of Meat and Meat Products. [Price, J.F. and Schweiwert, B.S. (eds.)], W.H. Freeman and Co., San Francisco.
Dharmaveer, S., Rajkumar, V. and Mukesh, K.P. (2007). Quality and shelf life of smoked chevon sausages packed under vacuum and stored at $4 \pm 1^{\circ} \mathrm{C}$. American. Journal of Food Technology. 2: 238-247.

Gao, X.Q., Zhang, W.G. and Zhou, G.H. (2014). Effects of glutinous rice flour on the physiochemical and sensory qualities of ground pork patties. Journal of Food Science and Technology. 58: $135-141$.

Goffman, F.D. and Bergman, C.J. (2004). Rice kernel phenolic content and its relationship with antiradical efficiency. Journal of Science and Food Agriculture. 84:1235-40.

Hu, C., Zawistowski, J., Ling, W. and Kitts, D.D. (2003). Black rice [Oryza sativa (L.) indica] pigmented fraction suppresses both reactive oxygen species and nitric oxide in chemical and biological model systems. Journal of Agricultural Food Chemistry. 51: 5271-77.

Hussein, S.A. (2015). Utilization of black rice and red sorghum hull as natural antioxidant on the quality attributes of fish fingers. Middle East Journal of Agriculture. 4: 509-518.

Hwang, Y.H., Yang, H.S., Jeong, J.Y., Kim, G.D., Park, G.B. and Joo, S.T. (2009). Properties of flours. Poultry Science. 88: $1452-1458$.

Ichikawa, H., Ichiyanagi, T., Xu, B., Yoshii, Y., Nakajima, M. and Konishi, T. (2001). Antioxidant activity of anthocyanin extract from purple black rice. Journal of Medicinal Food. 4: $211-218$.

Jebin, N., Laskar, S.K., Hazarika, M., Nath, D.R., Rahman, Z. and Chavhan. D.M. (2012). Effect of incorporation of glutinous rice flour on quality of duck meat salamis. Journal of Meat Science. 8: 76-79.

Kumar, V., Biswas, A.K., Sahoo, J., Chatli, K.M.and Sivakumar, S. (2013). Quality and storability of chicken nuggets formulated with green banana and soyabean hull flours. Journal of Food Science and Technology. 50: 1058-1068.

Laskar, S.K., Jebin, N., Nath, D.R. and Hazarika, M. (2013). Studies on composition and sensory quality of fat reduced Chevon salamis incorporated with glutinous rice flour. Asian Journal of Dairy and Food Resarch. 32(2): 149-151.

Lee, Y.C., Song, D.S. and Yoon, S.K. (2003). Effects of ISP adding methods and freezing rate on quality of pork patties and cutlets. Korean Journal of Food Science and Technology. 35: 182-187.

Mongale, C.W., Carpenter, J.A. and Reagan, J.O. (1985). The effects of soluble and insoluble components of beef skeletal muscle on the stability of meat batters. Journal of Food Quality. 8: 145-152.

Park, S.Y. and Kim, Y.H. (2016). Effects of Black Rice Powder Levels in Quality Properties of Emulsion- type Sausage. Korean Journal of Food Science. 36(6): 737-743.

Park, S.Y., Kim, H.Y., Kim, G.W. and Lee, J.W. (2017). Effect of black rice powder on the quality properties of pork patties. Journal of Food Science and Technology. 37(1): 71-78.

Pereira, J., Zhang, W. and Zhou, G. (2016). Effects of rice flour on emulsion stability, organoleptic characteristics and thermal rheology of emulsified sausage. Journal of Food and Nutrition Research. 4(4): 216-222.

Philpott, M., Gould, K.S., Lim, C. and Ferguson, L.R. (2006). In situ and in vitro antioxidant activity of sweet potato anthocyanins. Journal of Agricultural Food Chemistry. 54: 1710-5. 
Pippen, E.L., De Fremery, D., Limeweaver, H. and Hanson, H.L. (1965). Chicken broth flavour and $\mathrm{pH}$. Poultry Science. 44: 816.

Reddy, B.O., Indumathi, J. and Reddy, G.V.B. (2015). Binders as functional ingredients in meat products- An overview. International Journal of Development Reearch. 5(8): 5311-5316.

Reddy, N.S.P., Reddy, M.S. and Reddy, K.S. (1999). Influence of inclusion of non-meat extenders in mutton sausages on its quality. Indian Food Packer. March-April: 20-21.

Verma, A.K. and Banerjee, R. (2012). Low-sodium meat products: Retaining salty taste for sweet health. Critical Reviews in Food Science and Nutrition. 52(1): 72-84.
Wardlaw, E.R., McCaskill, L.M. and Acton, J.C. (1973). Effect of post mortem muscle changes on poultry meat loaf properties. Journal of Food Science. 38: 421.

Witte, V.C., Krause, G.F. and Barley, M.E. (1970). A new extraction method for determining 2-thiobarbituric acid values for pork and beef during storage. Journal of Food Science. 35: 582.

Yi, H.C., Cho, H., Hong, J.J., Ryu, R.K., Hwang, K.T. and Regenstein, J.M. (2012). Physicochemical and organoleptic characteristics of seasoned beef patties with added glutinous rice flour. Meat Science. 92: 464-468. 